\title{
Implementation of TPM in cellular manufacture
}

\author{
G. Chand, B. Shirvani* \\ Faculty of Engineering and Computer Technology, University of Central England, Birmingham, B42 2SU, UK
}

\begin{abstract}
A fundamental component of world-class manufacturing (WCM) is that of total productive maintenance (TPM), linked to both total quality management (TQM) and the concepts of continuous-flow manufacturing which are embedded in cellular manufacturing.

An investigation was conducted in collaboration with a first tier automotive component supplier to determine the overall equipment effectiveness (OEE) of a semi-automated assembly cell. The big losses associated with equipment effectiveness were also identified.

The production output of the cell over the observed period was 26515 . This represents $97 \%$ good components, $0.33 \%$ scrap and $2.67 \%$ rework. The number of stoppages recorded was 156 , where the 10 most common causes were identified. The OEE was $62 \%$ and the six big losses represent $38 \%$ loss of the productive time.

Based on the findings, it was recommended that a pilot project to be conducted to implement a TPM programme for the cell and expand it further to the other cells in the factory. (C) 2000 Elsevier Science S.A. All rights reserved.
\end{abstract}

Keywords: Total productive maintenance; Planned preventive maintenance; World class manufacture; Overall equipment effectiveness and just-in-time

\section{Introduction}

The collaborating company is internationally oriented, and is one of the leading suppliers of automotive components world-wide. The UK operation is a newly founded member of this global organisation and has recently established itself in the UK market due to the competitively fierce and global scope of demand placed for their products; inconjunction to the ever growing automotive investments in the UK markets.

Aware of the need for change of culture, the company has recently acquired BS EN ISO 9000 accreditation, and is currently preparing to gain the newly recognised QS 900 certification.

As part of the company's strategic plan in pursuit of world-class manufacturing (WCM) status, it is required to implement a total productive maintenance (TPM) programme in order to ensure smooth operation under the constraints of a just-in-time (JIT) production environment.

A feasibility study was conducted on a semi-automated assembly cell, in order to determine the OEE of the cell as well as establishing the associated big losses.

\footnotetext{
* Corresponding author.

E-mail address: bez.shirvani@uce.ac.uk (B. Shirvani)
}

\subsection{Companys manufacturing and operation strategies}

The new modern built plant has recently set-up on a green-field site, and employs around 150 people. The manufacturing layout comprises of three distinct cells which are gradually becoming more customer-focused. The 'JIT' philosophy and the overall shop-floor layout and it's facilities which incorporates a kanban system, helps ensure that production scheduling is customer-based, as opposed to capacity-based.

The production operation includes: forming shop, toolroom and a fully equipped product test-room. There are three assembly cells: semi-automated, manually-operated and flexible cell.

An integrated computer system is used to control and monitor production planning and scheduling which provides accurate and 'real-time' processing of information to control production progress which is linked to an electronic data interchange (EDI) system for scheduling and customer order processing.

\subsection{Global competition}

The automotive component industry is undergoing radical changes, and customers are placing greater expectations due to competitively fierce and ever increasing global sourcing. 


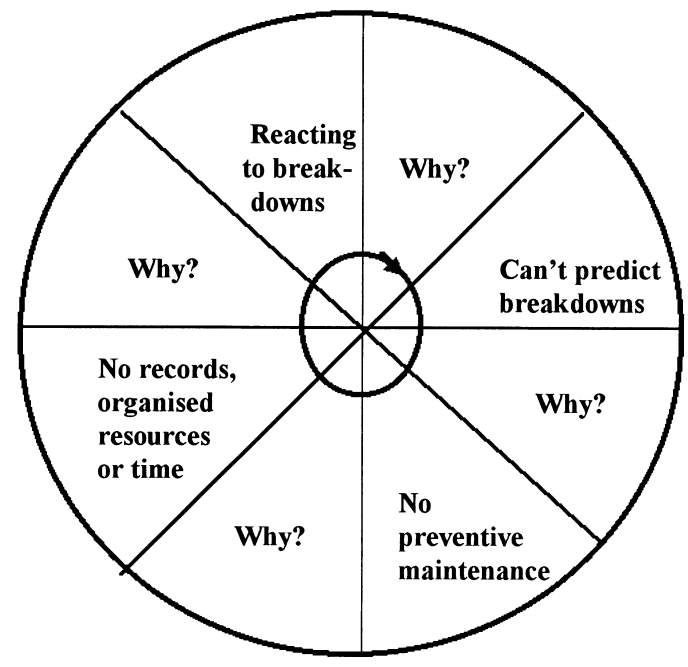

Fig. 1. The vicious circle of reactive maintenance.

The UK operation is even faced with competition from different plants world-wide within the same organisation. As a result, the company must ensure that total customer satisfaction is met in combined terms of quality, price, delivery, and product choice.

\section{Current maintenance system}

Current maintenance in the company is based on traditional practices and is reactive, i.e., breakdown. It is a practice that is inherently wasteful and ineffective with disadvantages such as: unscheduled downtime of machinery, possibility of secondary damage, no warning of failure with possible safety risks, production loss or delay, and the need for standby machinery where necessary.

TPM will enable the company's traditional maintenance practices to change from reactive to proactive by sharing responsibility for machine condition, performance and maintenance. Fig. 1 illustrates the vicious circle of reactive maintenance which should be broken [1].
Reactive maintenance will lead to machinery condition and general state of facilities becoming locked into a downward spiral leading to further deterioration and more and more problems. Thus, the real cost of reactive maintenance is much more than the cost of maintenance resources and spare parts as indicated in Fig. 2.

\section{TPM and world-class manufacturing}

The purpose of any manufacturing enterprise is to consistently make a profit. Being world-class in manufacturing means that the company can compete successfully and make profit in an environment of international competition, not only now, but also in the future. In essence, being worldclass means being capable of bringing products to the marketplace that offers better value than the competition without loss of profit going broke [4]. The TPM component of WCM, is linked to both TQM and the concepts of continuous-flow manufacturing, which are embodied in cellular manufacturing. TPM incorporates the strategies of operator ownership and systematic planned preventive maintenance (PPM) activities to keep machines from breaking down or malfunctioning during production. Overall, it is clear that the components of WCM, whilst not sequential in implementation, are certainly highly interrelated. It is not possible, for example, to be a flexible, WCM, JIT producer with poor equipment and second-rate quality systems [3].

\subsection{Definition and distinctive features of TPM}

TPM as defined by [2] is "productive maintenance involving total participation". The goal of TPM is to enhance equipment effectiveness and maximise equipment output. It strives to attain and maintain optimal equipment conditions in order to prevent unexpected breakdowns, speed losses, and quality defects in process. Overall efficiency, including economic efficiency, is achieved by operating at optimal conditions through the life of equipment, i.e., by minimising life cycle cost (LCC). A complete definition of TPM includes the following five activities:

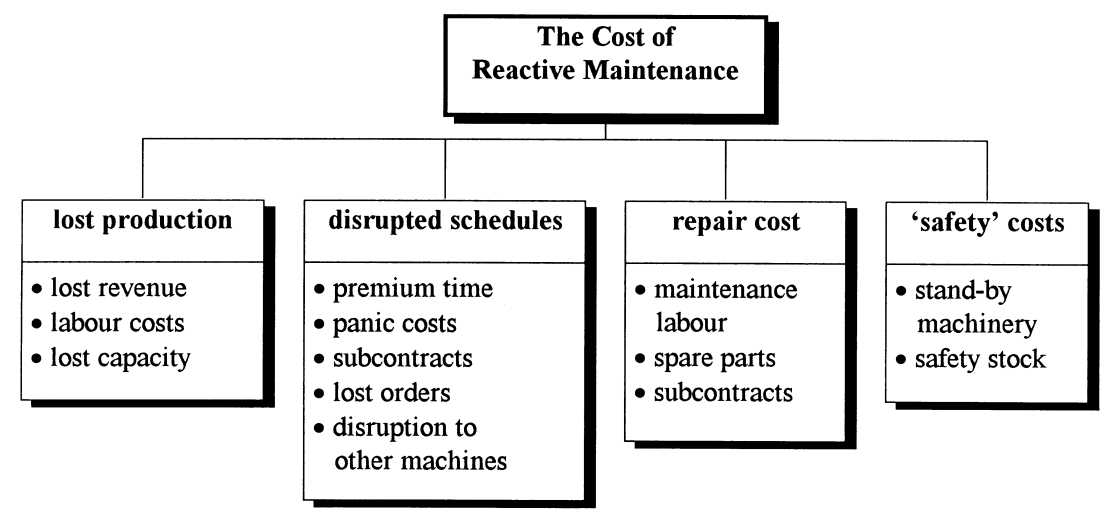

Fig. 2. The real cost of reactive maintenance. 
- To maximise overall equipment effectiveness.

- To establish a thorough system of PPM for the equipment's entire life span.

- To include all departments in implementation plan.

- To involves every single employee, from top management to shop-floor operators.

- To promote PPM through autonomous small group activities.

Equipment effectiveness is maximised and life cycle cost minimised through company-wide efforts to eliminate the following "six big losses" that reduce equipment effectiveness, these are [2]:

\section{- Downtime losses}

- Failures. Downtime losses caused by unexpected breakdowns.

- Set-up and adjustments. Downtime losses due to setup and adjustments such as exchanging dies in presses and plastic injection moulding machines.

- Speed losses

- Idling and minor stoppages. Idling and minor stoppages caused by the malfunction of sensors and blockages of work on chutes.

- Reduced speed. Losses caused by the discrepancy between the designed speed and the actual speed of equipment.

- Defect losses

- Defects in process. Losses caused by defects and the reworking of defects.

- Reduced yield. Reduced yield losses that occur between start-up and stable production.

\section{The assembly cell}

The assembly cell selected to conduct the feasibility study was a semi-automated cell controlled by three production operatives, and supplies three types of product designs. The production cell comprised of seven workstations with individual on-board computer control panels. Parts are fed via a powered belt conveyor. The manual operations only include loading/unloading the component parts, fitting clips, final visual inspection, and packaging.

\subsection{The operators}

The three production operators are fully trained in operating the line. They are capable of carrying out some simple tooling and process adjustments such as setting/re-setting stations via the on-board control panels. However, the cell is continuously monitored and controlled by a production technician who performs tool changes, rework, quality control checks, and aids when breakdowns occur during the production process.

\subsection{Quality control and inspection}

The cell is regularly inspected daily during the morning, afternoon and night shift. The individual stations perform specific test, which includes; testing of the detection laser and sensors, and inspection of pressure tester for vacuum test at Station 7.

The operator's perform visual inspection prior to packaging, to check for any type of defect (e.g., scratches on cover, shorts, tool marks, etc.), and necessary rework (e.g., rivets not screwed in properly). All defects are noted on an assembly attribute control chart.

\subsection{Maintenance on the cell}

PPM has been recently devised for the cell and involves various cleaning and testing procedures. Maintenance tasks are carried out by the maintenance personnel, weekly during the night shift on Wednesday and Friday. The operators are only responsible for the good housekeeping of the cell. These PPM schedules were implemented at the beginning of 1998 , demonstrating the company links with TPM.

\section{Data capture and analysis}

The cell was monitored over a period of 4 weeks. The operation is based on three shifts per day (one shift for Saturday only), six days per week. This accumulates to 16 shifts and $125 \mathrm{~h}$ of operation. The planned downtime per shift was $15 \mathrm{~min}$ at the end of each shift for cleaning/tidyingup the work area, machines and complete any associated paperwork. During this period, activities such as stoppage, speed reduction, set-up/adjustments, quality impaired and reworks were recorded. The total number of stoppages was 156 and the production output was as follows:

Total number of products produced

Total number of re-work

Total number of scraping

87

Total number of quality products

25718

\subsection{Measuring overall equipment effectiveness}

The goal of TPM is to increase equipment effectiveness so each piece of equipment can be operated to its full potential and maintained at that level. The cell suffers from losses that prevent effective operation. These losses are caused by operator actions and equipment faults. In order to improve the effectiveness of the cell, it is important to recognise, measure and reduce these losses. The most effective method is to analyse the OEE of the cell. The OEE is a measure of the value added to production through equipment, which is a function of machine availability, performance efficiency and the rate of quality. The relationship between these parameters and major losses are shown in Fig. 3 [2]. 




Fig. 3. Measuring OEE.

\subsubsection{Measuring equipment productivity}

The true performance of the equipment productivity is measured by total effective equipment productivity (TEEP), and is a combined measure of equipment utilisation (which includes planned downtime) and OEE. The latter can be improved at the expense of equipment utilisation by scheduling PPM and product changeovers during planned downtime.

The OEE is not an exact measure of equipment effectiveness as set-up, changeovers and adjustments are included. Therefore, to provide a more accurate analysis, the net equipment effectiveness (NEE) can be measured that reflects the true quality and effectiveness of the equipment when running.

\subsubsection{Calculations of TEEP, OEE, and NEE \\ Utiisation}

Total running time $=125 \mathrm{~h}$ per week $\times 4$ weeks

$$
\times 60=30000 \mathrm{~min}
$$

Planned downtime (excluding set-up and adjustments)

$$
=240+255+300+240=1035 \min
$$

(Total running time - Planned downtime $) \times 100$

$$
\text { Total running time }
$$

$$
=\frac{(30000-1035) \times 100}{30000}=96 \%
$$

\section{Planned availability}

Loading time $=$ Running time - Planned downtime

$$
=30000-1035=28965 \mathrm{~min}
$$

Set-up and adjustments $15 \mathrm{~min}$ per tool change

$$
\times 15 \text { changes }=225 \mathrm{~min}
$$

Planned availability

$$
\begin{aligned}
& =\frac{(\text { Loading time }- \text { Set-up time }) \times 100}{\text { Loading time }} \\
& =\frac{(28965-225) \times 100}{28965}=99 \%
\end{aligned}
$$

\section{Actual availability}

Actual availability

$$
\begin{aligned}
& =\frac{(\text { Loading time }- \text { Set-up time }- \text { Downtime }) \times 100}{\text { Loading time }} \\
& =\frac{(28965-225-4656) \times 100}{28965}=84 \%
\end{aligned}
$$

Net equipment effectiveness

Operating time $=5470+6275+6320+6090$

$$
+24155 \mathrm{~min}
$$

Equipment failures (excluding set-up and adjustments)

$$
=(1781+975+880+1170)-225=4581 \mathrm{~min}
$$

\section{Uptime}

$$
\begin{aligned}
\text { Uptime } & =\frac{(\text { Operating time }- \text { Equipment failures }) \times 100}{\text { Operating time }} \\
& =\frac{(24155-4581) \times 100}{24581}=81 \%
\end{aligned}
$$

\section{Performance efficiency}

Operating time $=24155 \mathrm{~min}$

Average cycle time $=0.75 \mathrm{~min} /$ unit

$\times$ (components supplied from machine)

$=0.66 \mathrm{~min} /$ unit (components supplied from stores)

Average cycle time $=\frac{(0.73+0.72+0.69+0.71)}{4}$

$$
=0.71 \mathrm{~min} / \text { unit }
$$

Number of good units made

$$
=5588+6655+6800+6675=25718
$$

Performance efficiency

$=\frac{(\text { Average cycle time } \times \text { No. of good units made }) \times 100}{\text { Operating time }}$

$$
=\frac{(0.71 \times 25718) \times 100}{24155}=76 \%
$$

Rate of quality

Number of good units made $=25718$ 
Scrap units and rework $=234+173+109+281=797$

Rate of quality

$$
\begin{aligned}
& =\frac{(\text { Number of good units made }- \text { Rejects }) \times 100}{\text { Number of good units made }} \\
& =\frac{(25718-797) \times 100}{25718}=97 \%
\end{aligned}
$$

\section{TEEP}

$\mathrm{TEEP}=$ Utilisation $\times$ Availability $\times$ Performance efficiency $\times$ Rate of quality $\times 100=0.96 \times 0.84 \times 0.76$

$$
\times 0.97 \times 100=59 \%
$$

\section{OEE}

$\mathrm{OEE}=$ Availability $\times$ Performance efficiency

$\times$ Rate of quality $\times 100=0.84 \times 0.76 \times 0.97 \times 100$ $=62 \%$

\section{NEE}

$\mathrm{NEE}=$ Uptime $\times$ Performance efficiency

$$
\begin{aligned}
& \times \text { Rate of quality } \times 100=0.81 \times 0.76 \times 0.97 \\
& \times 100=60 \%
\end{aligned}
$$

\subsection{The cost of the six big losses}

The cost of components is $£ 8.50$ and the cost of assembled product is $£ 10.00$. Therefore the assembly process has earned $£ 1.50$ (added value) for the company. If the expected theoretical output is 80 components every hour, then the added value per hour can be calculated as

Added value $/ \mathrm{h}=£ 1.50 \times 80=£ 120 / \mathrm{h}$

The expected throughput is based upon the theoretical cycle time for the assembly process, and does not take into consideration the six big losses associated with the machinery. Therefore, having measured the OEE of the cell at $62 \%$, then the actual added value per hour can be calculated as

Actual added value per hour $=\frac{£ 120 \times 62}{100}=£ 74.40 / \mathrm{h}$

Thus, the six big losses represent a loss of added value of $£ 45.60 / \mathrm{h}$ ( $38 \%$ loss of OEE). The annual loss can be determined by estimating the average loading of the cell during the year. For instance, if the cell was used on a threeshift basis, and operated on average $117 \mathrm{~h}$ per week (excluding Saturday overtime), and for 48 weeks per year, then the average loading can be calculated as

Average loading $=117 \mathrm{~h} \times 48$ weeks $=5616 \mathrm{~h}$ per year

Therefore, the annual loss is the product of the loading hours and loss per hour.

Annual loss $=£ 45.60 \times 5616 \mathrm{~h}=£ 256089$
Thus, the cell could have potentially earned an additional $£ 256089$ for the company if it operated at $100 \%$ effectiveness as opposed to $62 \%$ effectiveness. However, if the company can reach the more realistic world-class target of $85 \%$ OEE, then every $1 \%$ improvement towards the target of $85 \%$ OEE can be calculated as

$1 \%$ improvement $=\frac{£ 256089}{38 \%} £ 6739.18$

Thus, if the world-class target of $85 \%$ was reached, then the $23 \%$ increase of OEE would represent an earning capacity of

$23 \%$ improvement $=£ 6739.18 \times 23=£ 155000$

\section{Discussion and conclusion}

\begin{tabular}{ll}
\hline Company's cell performance World-class performance \\
\hline $84 \%$ Availability & $>90 \%$ Availability \\
$\times$ & $\times$ \\
$76 \%$ Performance efficiency & $>95 \%$ Performance efficiency \\
$\times$ & $\times$ \\
$97 \%$ Rate of quality & $>99 \%$ Rate of quality \\
$=$ & $=$ \\
$62 \%$ OEE & $>85 \%$ OEE \\
\hline
\end{tabular}

Therefore if the WCM target of $85 \%$ OEE was reached, then $23 \%$ increase would have represented a potential earning capacity of $£ 155000$ per annum.

The efficient maintenance of the production and other plant machinery is crucial in determining the success and overall effectiveness of the manufacturing process. Despite time and money spent on the development/production of the advanced plant and its equipment, there has not been enough attention to defining comprehensive maintenance strategies, practices and policies. However, there are indications that the transition process from reactive (breakdown) maintenance to preventive maintenance is already taking place.

In order to establish autonomous maintenance teams, a better communication and team-work must be promoted. It is essential that the company devises an efficient data recording system, so that up-to-date and accurate information will be available to the management.

The process of recording information must remain simple, but effective for future data analysis. If provisions were made to highlight such problems and possible causes, then it may lead to the correction of common problems such as breakdowns and re-work. Ultimately, if possible, the aim is to eliminate such causes.

Information provided by the trend analysis can provide a basis for forming long-term plans. The maintenance department can plan spending requirements by using historical information to state the return on investment when contributing to the annual business plan of the company. The 
availability of relatively cheap computing power makes this process feasible and financially attractive.

The principle of using localised data gathering and information processing, rather than a computer maintenance management system (CMMS), recognises the important role of the operators. This does not replace the need for a CMMS to monitor costs, control spares and schedule planned preventive maintenance. A local PC-based facility-performance measure can be seen as enhancing existing CMMS.

It is recommended that the company can go ahead with plans to implement TPM. Further research is also to be conducted into the introduction of a facility performance log system, and single minute exchange of die (SMED) for the manually-operated cells and machines as their set-up times were too excessive (up to $2 \mathrm{~h}$ ).

\section{References}

[1] R. Davis, Productivity Improvements Through TPM, Prentice-Hall, Englewood Cliffs, NJ, 1995 (Chapters 2 and 3).

[2] S. Nakajima, Introduction to Total Productive Maintenance (TPM), Productivity Press, Cambridge, MA, USA, 1988 (Chapter 1).

[3] J.H. Steudel, Manufacturing in the Nineties - How to Become a Mean, Lean, World-Class Competitor, Van Nostrand Reinhold, New York, 1992, pp. 2-15.

[4] J. Todd, World-class Manufacturing, McGraw-Hill, New York, 1995, pp. 83-92. 